\title{
Vaginal forløsning ved seteleie
}

$96 \%$ av fødslene til termin skjer med fosteret i hodeleie. Et foster som ligger i seteleie til termin er altså en sjeldenhet. Hvilke mekanismer som initierer at fosteret spontant legger seg i hodeleie er fortsatt ukjent, men en rekke studier har vist at fostre som til slutt ender opp med å bli født i seteleie har flere fellestrekk. De fødes oftere for tidlig enn andre barn, og det er en økt forekomst av misdannelser. Fødselsvekten er lavere og navlesnoren kortere. Seteleie viser familiær opphopning, og en mor eller far født i seteleie har en høyere andel av barn født i seteleie (1). Det er ikke mulig å avgjøre hvorvidt disse faktorene er medvirkende årsaker til eller er forårsaket av at fosteret ligger i seteleie. Fortsatt har vi for lite kunnskap til å si noe om hvorvidt disse forholdene har innflytelse på fosterets evne til å takle den normale fysiologiske reaksjonen ved en vaginal fødsel.

I dagens fødselshjelp er ultralyd et naturlig og selvfølgelig redskap hvis fødselshjelperen er usikker på tolking av palpasjonsfunnene. Andreasen og medarbeidere beskriver i dette nummer av Tidsskriftet fødselsmetoden ved seteleie ved sin avdeling (2). De fant at blant barna med seteleie ble det utført akutt keisersnitt på indikasjon fotleie hos $22 \%$. Fotleie ved fødsel til termin forekommer meget sjelden. Det betyr at en betydelig andel av disse var utført på bakgrunn av feiltolking av palpasjonsfunn. Denne form for feiltolking er også tidligere beskrevet. Bruker man de redskaper som er tilgjengelig, som for eksempel ultralyd, vil man kunne unngå keisersnitt på feil indikasjon.

I de siste ti årene har diskusjonen om den anbefalte forløsningsmetoden ved seteleie til termin vært preget av konklusjonen i Term Breech Trial (3). I studien konkluderte man med å anbefale elektivt keisersnitt ved seteleie. Allerede kort tid etter publisering ble studien gjenstand for kritikk. I hovedsak rettet den seg mot for dårlig utvelgelse av inkluderte kasus, uensartet intrapartumoppfølging, at fødeinstitusjoner med forskjellig kompetansenivå ble analysert sammen og at korttidsmorbiditet ble anvendt som markør for langtids nevrologisk påvirkning. I Norge ble det nedsatt en egen gruppe i regi av Senter for medisinsk metodevurdering som kom med en norsk anbefaling i 2003. Konklusjonen til gruppen var at ved seteleie til termin kunne man etter seleksjon anbefale vaginal forløsning (4).

I 2004 ble oppfølgningsstudien til Term Breech Trial publisert. Etterundersøkelsen av barna ved toårsalderen viste at det var sikkert å føde vaginalt i seteleie, selv med de begrensninger og mangler som ble påpekt i studien (5). I 2006 ble resultatene fra PREMODAstudien publisert, en deskriptiv studie der prospektive data fra 8105 fødsler ble inkludert (6). I denne studien, som er basert på data fra moderne velutstyrte obstetriske enheter, konkluderte man med at det er trygt å forløse seteleie vaginalt etter seleksjon. I 2006 endret både American College of Obstetricians and Gynecologists og det britiske Royal College of Obstetricians and Gynecologists sine restriktive anbefalinger fra 2001 til å anbefale selektert vaginal forløsning ved seteleie. Dette ble i 2009 fulgt opp av Society of Obstetricians and Gynaecologists of Canada, som nå også anbefaler selektert vaginal forløsning ved seteleie (7).

Der hvor man har «gjenopptatt» vaginal seteforløsning, har man en stor utfordring i å gjenetablere tapte ferdigheter. Reelt var andelen som fødte vaginalt i seteleie allerede forut for publiseringen av Term Breech Trial så lav mange steder at det var vanskelig for fødselshjelperne å opprettholde kompetansen i vaginal seteforløsning. Også i Norge har vi en rekke praktiske og pedagogiske utfordringer som må løses for å sikre at kompetansen opprettholdes og bringes videre til neste generasjon av fødselshjelpere. Jeg tror ikke det vil være mulig å opprettholde denne på alle fødeinstitusjoner i Norge. De siste årene har vaginal setefødsel utgjort ca. $1 \%$ av fødepopulasjonen. Dermed blir det absolutte antallet av vaginale setefødsler lavt på fødeinstitusjoner med få fødsler. For å sikre opplæringen fremover bør det vurderes om vi i høyere grad skal samle seteforløsningene på fødeavdelinger med kompetanse i vaginal forløsning.

Det er nødvendig å ivareta alle aspekter av den praktiske obstetrikken for å sikre god fødselshjelp. Vaginal forløsning av seteleie representerer kun en liten andel av våre forløsninger, men er en av de obstetriske utfordringene der det er nødvendig å beherske de riktige håndgrepene. Alle fødselshjelpere må sikres opplæring i praktisk obstetrikk innbefattende grunnleggende fødselsmekanikk, vaginal operativ forløsning med bruk av tang eller vakuum, vaginal forløsning av seteleie, forløsning av tvillinger og keisersnittforløsning. Risikoen for å få et uønsket fødselsutfall vil aldri bli null, uansett leie eller forløsningsmåte, men det må i moderne obstetrikk være et hovedmål å redusere risikoen for både mor og barn til et minimum. Et minstemål må være at vi er klar over egne rutiner. Å evaluere aktivitet på egen fødeavdeling, slik Andreasen og medarbeidere har gjort, er en fin mulighet til å få innsikt $\mathrm{i}$ hvorvidt de beslutninger som treffes i en travel klinisk hverdag er i overensstemmelse med egne og nasjonale anbefalinger.

\section{Susanne Albrechtsen}

susanne.albrechtsen@helse-bergen.no

Susanne Albrechtsen (f. 1960) er seksjonsoverlege på fødeseksjonen, Kvinneklinikken, Haukeland universitetssykehus.

\section{Litteratur}

1. Nordtveit TI, Melve KK, Albrechtsen S et al. Maternal and paternal contribution to intergenerational recurrence of breech delivery: population based cohort study. BMJ 2008; 336: 872-6.

2. Andreasen S, Nielsen EW, Øian P. Fødselsmetode ved seteleie. Tidsskr Nor Legeforen 2010; 130: 605-8.

3. Hannah ME, Hannah WJ, Hewson S et al. Planned caesarean section versus planned vaginal birth for breech presentation at term: a randomized multicentre trial. Lancet 2000; 356: 1375-83.

4. Øian P, Albrechtsen S, Berge LN et al. Fødsel av barn i seteleie til termin. SMM-rapport nr. 3/2003. www.kunnskapssenteret no/Publikasjoner/3599.cms (9.3.2010)

5. Whyte H, Hannah ME, Saigal S et al. Outcomes of children at 2 years after planned cesarean birth versus planned vaginal birth for breech presentation at erm: the international randomized Term Breech Trial. Am J Obstet Gynecol 2004: 191: $864-71$

6. Goffinet F, Carayol M, Foidart JM et al. PREMODA Study Group. Is planned vaginal delivery for breech presentation at term still an option? Results of an observational prospective survey in France and Belgium. Am J Obstet Gynecol 2006: 194: 1002-11.

7. Kotaska A, Menticoglou S, Gagnon R. Vaginal delivery of breech presentation. J Obstet Gynaecol Can 2009; 31: 557-66. 